\title{
The multiple effects of thyroid disorders on bone and mineral metabolism
}

\author{
Os múltiplos efeitos das disfunções tireoidianas \\ sobre o metabolismo osteomineral
}

Ludmilla F. Cardoso', Léa M. Z. Maciel', Francisco J. A. de Paula'

'Department of Internal Medicine, Ribeirão Preto Medical School, University of São Paulo (FMRPUSP), Ribeirão Preto, SP, Brazil

\author{
Correspondence to: \\ Francisco J. A. de Paula \\ Av. Bandeirantes, 3900 \\ 14049-900 - Ribeirão Preto, SP, Brazil \\ fjpaula@fmrp.usp.br \\ Received on Feb/25/2014 \\ Accepted on May/12/2014 \\ DOI: 10.1590/0004-2730000003311
}

\begin{abstract}
Differently from most hormones, which commonly are specialized molecules able to influence other cells, tissues and systems, thyroid hormones (TH) are pleiotropic peptides, whose primordial function is difficult to identify. The complex action of TH on human economy can be easily witnessed by examining the diverse consequences of TH excess and deficiency during development and after maturity. In particular, different manifestations in bone modeling and remodeling reflect the circumstantial consequences of thyroid disturbances, which are age dependent. While hyperthyroidism during childhood enhances bone mineralization and accelerates epiphyseal maturation, in adults it induces bone loss by predominant activation of osteoclast activity. Furthermore, the syndrome of TH resistance is a multifaceted condition in which different sites exhibit signs of hormone excess or deficiency depending on the configuration of the TH receptor isoform. The investigation of the impact of TH resistance on the skeleton still remains to be elucidated. We present here a thorough review of the action ofTH on bone and of the impact of thyroid disorders, including hyper- and hypothyroidism and the syndrome of $\mathrm{TH}$ resistance, on the skeleton. Arq Bras Endocrinol Metab. 2014;58(5):452-63
\end{abstract}

\section{Keywords}

Thyroid hormones; osteoporosis; thyrotoxicosis; hypothyroidism; thyroid hormone resistance

\section{RESUMO}

Diferentemente da maioria dos hormônios, que usualmente são moléculas especializadas capazes de influenciar outras células, tecidos e sistemas, os hormônios da tireoide (HT) são peptídeos pleiotrópicos, cuja função primordial é difícil de identificar. A ação complexa dos HT na fisiologia humana pode ser facilmente reconhecida ao observar as diversas consequências do excesso e da deficiência de HT durante e após o pleno desenvolvimento. Em particular as diferentes manifestações na modelação e remodelação óssea refletem que as consequências esqueléticas das disfunções tireoidianas dependem das circunstâncias e variam com a idade. Enquanto o hipertireoidismo durante a infância aumenta a mineralização óssea e acelera a maturação epifisária, em adultos induz a perda óssea pela ativação predominante da ação osteoclástica. Além disso, a síndrome de resistência ao HT é uma condição multifacetada na qual diferentes tecidos apresentam sinais de excesso ou deficiência hormonal, dependendo da predominância da expressão das diversas isoformas do receptor de HT. O impacto da resistência ao HT sobre o esqueleto ainda é motivo de investigação. Apresentamos aqui uma revisão abrangente sobre as ações ósseas dos HT e o impacto no esqueleto dos distúrbios da tireoide, incluindo hipo e hipertireoidismo e síndrome de resistência ao HT. Arq Bras Endocrinol Metab. 2014;58(5):452-63

\section{Descritores}

Hormônios tireoidianos; osteoporose; tireotoxicose; hipotireoidismo; resistência ao hormônio tireoidiano 


\section{INTRODUCTION}

$\mathrm{T}$ hyroid hormones $(\mathrm{TH})$, vitamin $\mathrm{D}(\mathrm{VD})$ and steroids belong to a special group of endocrine molecules which produce their effects by signaling in nuclear receptors (NR) (1). Typically they are pleiotropic hormones, affecting a significant range of cell types in most tissues and in various systems. In common $\mathrm{TH}$, steroids and VD also have intense effect on bone strength and on mineral and energy metabolism. While glucocorticoids and gonadal steroids, respectively, lead to a loss and an increase in bone mass, $\mathrm{TH}$ have a more complex effect depending on age, circumstances.

The TH 3,5,3',5'-tetraiodo-L-thyronine (thyroxin or T4) and 3,5,3'-triiodothyronine (T3) are produced and secreted by thyroid follicles which, under TSH stimulation, capture iodide through the membrane protein NIS (a iodide-sodium cotransporter) and utilize it for TH synthesis. T4 is considered to be a prohormone whose main function is to serve as a substrate for the production of $\mathrm{T} 3$ through deiodination by the type 1 (D1) and type 2 (D2) deiodinase enzymes. T3 is the main hormone responsible for the genomic actions of $\mathrm{TH}$, modulating the expression of target genes after binding to the $\mathrm{TH}$ receptor (TR), while $\mathrm{T} 4$, reverse T3 (rT3) and 3,5-diiodothyronine (T2) seem to be more involved in non-genomic TH actions, which occur more rapidly and usually in consonance with their genomic actions. These last hormones are also fundamental for the regulation of basal cell activity and are important for rapid adjustments of cell homeostasis (1).

Once released into the blood circulation, $\mathrm{TH}$ are transported to the intracellular medium by $\mathrm{TH}$ transporters (THT), which have 12 transmembrane domains and can be divided into two subfamilies: organic anion transporters (NTCP and OATP) and amino acid transporters (L type - LAT1 and LAT2, and T type - MCT8 and MCT10). The only THT specific for TH is MCT8, while all the others are denoted secondary transporters (2).

Inside the cell, $\mathrm{T} 3$ binds to $\mathrm{TR}$, which belongs to the superfamily of NR and is usually found in the nucleus as a heterodimer with the retinoid $\mathrm{X}$ receptor (RXR), modulating gene transcription. Thus, NR are transcription factors activated by their ligands, proteins that bind to the promoter region of target genes in order to activate or repress transcription. In the absence of T3, TR recruits corepressor complexes (CoR) which compact chromatin by means of histone acetylation and prevent the action of the transcription machinery. T3 binding to TR changes its tridimensional conformation, which then shows greater affinity for coactivator complexes (CoA). As a consequence, $\mathrm{CoR}$ dissociation occurs, leading to histone acetylation and chromatin loosening, with the subsequent transcription of the target gene (1). The biological genomic activity of TH depends on the intracellular concentrations of T3, on D1 and D2 activity, and also on the activity of type 3 deiodinase (D3), which inactivates T3.

TR are coded by the THRA (c-erbA $\alpha)$ and THRB (c-erbA $\beta$ ) genes, respectively located on chromosomes 17 and 3 , which code by alternative splicing various isoforms distributed in the organism depending on tissue and on age. While TR $\beta$ predominates in the hypothalamus-pituitary region, the liver and kidneys, $\mathrm{TR} \alpha$ is the primary effector of the actions of $\mathrm{T} 3$ on the heart, central nervous system, intestine, skeletal muscle, and bone (3). Different isoforms have diverse effects, as can be observed in experimental models using knockout mice, in which the deletion of different types of TR leads to diverse manifestations.

\section{MATERIALS AND METHODS}

The platform Medline-PubMed database, followed by the Embase and Scientific Electronic Library Online/ Latin American and Caribbean Health Science Literature (SciELO/Lilacs) databases were used to search articles. The search terms used were thyroid hormone and bone in association with one of the following: osteoporosis, calcium, phosphorus, thyroid hormone resistance and growth.

\section{Molecular actions of TH in the skeleton}

The ample interface between $\mathrm{TH}$ and bone metabolism is demonstrated by the variety of molecules related to the metabolism and action of $\mathrm{TH}$ expressed in skeletal tissue, such as TRs, THTs and deiodinases (4-6).

The actions of T3 in bone are complex and only partially understood; they occur through direct and indirect pathways during all phases of the bone remodeling cycle, and stimulate both bone formation and resorption $(7,8)$. For instance, during bone formation, T3 stimulates osteoblast proliferation, differentiation and apoptosis, and increases the expression of osteocalcin, type 1 collagen, alkaline phosphatase, metalloproteins, IGF-1 and its receptor (IGF-1R). Subsequently, during bone resorption, $\mathrm{T} 3$ increases the expression of important differentiation factors of the osteoclast li- 
neage such as interleukin 6 and prostaglandin E2 (5). Moreover, T3 acts in a synergistic manner with osteoclastogenic hormones such as parathyroid hormone (PTH) (9) and VD (10). It has also been demonstrated that $\mathrm{T} 3$ increases the expression of $\mathrm{mRNA}$ of the ligand of receptor activator of nuclear factor- $\kappa \beta$ (RANKL) in the osteoblast, which activates RANK present in osteoclast precursors a key step in the osteoclastogenesis (7).

The TR $\beta 1$ and TR $\alpha$ l isoforms are expressed in the stromal cells of bone marrow, chondrocytes, osteoblasts and osteoclasts. Quantitative RT-PCR studies have indicated that TR $\alpha \mathrm{l}$ expression is at least ten times higher than TR $\beta 1$ expression, indicating that TR $\alpha$ l is the predominant mediator of the actions of T3 on the skeleton. Studies on adult female rats treated with 3,5-dimethyl-4-(4-hydroxy-3-isopropylbenzyl) phenoxy acetic acid (GC-1), a TR $\beta$-selective analogue, have shown that chronic treatment with GC-1 does not change bone mass. Conversely, treatment with a supraphysiological dose of T3 equimolar to the GC-1 dose causes a generalized bone loss. Taken together, these findings support the concept that the osteopenic effects of T3 are mediated by TR $\alpha$ (11).

Studies using animal models genetically modified for TR and D2 and with congenital hypothyroidism have made important contributions to the understanding of osteomineral effects of TH. Table 1 lists various representative studies in this line of investigation. In general, these studies demonstrated that mice with mutation of TR $\alpha$ or of both $\alpha$ and $\beta$ receptors nearly show the same phenotype of retarded growth and bone maturation, with delayed ossification, reduced postnatal growth and bone mineralization, delayed closure of the cranial sutures in early life and increased mineralization during adult life, as observed in hypothyroidism, although with less severity. In contrast, mice with mutation in TR $\beta$ gene show a thyrotoxic skeletal phenotype, with increased mineralization and advanced ossification which result in short stature and craniosynostosis in childhood and reduced mineralization and low bone mass in adulthood (12). However, the lower severity of the skeletal phenotype of TR mutants compared to mice with $\mathrm{TH}$ deficit or excess actually suggests a substantial overlap in the action of these two receptors regarding the control of bone development. Thus, up to a point, $\operatorname{TR} \beta$ and $\operatorname{TR} \alpha$ are interchangeable, although the compensatory effects are incomplete, with some effects being isoform-specific. In addition, TR $\alpha \mathrm{l}$ mutants exhibit reduced expression and signaling of $\mathrm{GH}$ and
IGF-1 receptors during the growth, suggesting that these receptors are targets of the physiological action of $\mathrm{T} 3$ on bone in vivo. In support to this point, there are studies demonstrating that IGF-I is stimulated by T3 in clones of cells of the osteoblast lineage (13).

Osteoblasts also express type 2 and 3 deiodinases, especially D2, the deiodinase that activates TH. D1 is not expressed in bone tissue (14). In addition, the THT is expressed in chondrocytes, osteoblasts and osteoclasts in all stages of cell differentiation, and the THT LAT 1 and LAT2 have been identified in mouse bone tissue and in cultures of osteoblast-like cells derived from mouse calvaria (MC3T3-El) (4). Similarly, expression of the TSH receptor (TSHR) has been demonstrated in osteoblasts and osteoclasts, suggesting that TSH may have direct effects on these cells (6). The identification of TSHR in various tissues including the brain, testicles, kidneys, heart, thymus, lymphocytes, adipose tissue, fibroblasts and bones suggests that TSH may play a broader role than its traditionally recognized stimulation of thyroid follicle cells (15). Some authors have proposed that TSH plays important roles on bone tissue, which are independent of the actions of TH (16). This is supported by studies on mice with deletion of the TSHR gene, which show high TSH and low serum levels of TH. TH therapy in these mice impacts body weight but does not affect bone mass or bone length (6). Alternatively, other authors (15) suggest that the failure in both bone mass gain and bone growth may be due to the remarkable delay of maturation during the period of prenatal hypothyroidism and during the three postnatal weeks that precede the beginning of TH replacement. Another study has suggested that TSH binding to its receptor in bone cells has beneficial effects on the skeleton through inhibition of osteoclastogenesis. In accordance to this tenet, $\mathrm{Ma}$ and cols. (16) suggested that in Graves disease the antibody TRAb decreases bone loss against the catabolic effects of high circulatory levels of $\mathrm{TH}$. The new evidence of the direct effects of TSH on bone, open the door to the investigation of additional mechanisms for the emergence of bone disease in thyroid disturbances. In the clinical setting, it will be challenging to define the contribution of TSH and THs to primary thyroid disorders. Nonetheless, further studies will be necessary to verify if bone catabolism is synergistically stimulated by suppressed serum TSH levels in primary hyperthyroidism and, conversely, if TSH has protective skeletal effects in primary hypothyroidism. 
Table 1. Skeletal phenotypes of genetic modified mice showing congenital hypothyroidism, TSH resistance, mutation in the type 2 deiodinase and thyroid hormone resistance alpha and/or beta

\begin{tabular}{|c|c|c|c|c|c|c|}
\hline Model & Genotype & Hormonal status & Young skeleton & Adult skeleton & $\begin{array}{c}\text { Skeletal } \\
\text { phenotype }\end{array}$ & References \\
\hline Pax8 & $\begin{array}{l}\text { Lack of essencial } \\
\text { transcriptor factor } \\
\text { Pax8 for thyroid } \\
\text { development }\end{array}$ & $\begin{array}{c}\text { No thyroid. } \\
\text { Undetectable TH; } \\
\text { elevated TSH } 2000 \\
\text { fold }\end{array}$ & $\begin{array}{l}\text { Serious and persistent } \\
\text { linear growth } \\
\text { retardation, delayed } \\
\text { endochondral } \\
\text { ossification, reduced } \\
\text { cortical bone, reduced } \\
\text { bone mineralization }\end{array}$ & NR & Hypothyroid & $\begin{array}{l}\text { Mansouri and cols. (61); } \\
\text { Friedrichsen and cols. (62) }\end{array}$ \\
\hline TSHR & TSHR deleted & $\begin{array}{l}\text { Thyroid hypoplasia. } \\
\text { Undetectable TH; } \\
\text { elevated TSH }\end{array}$ & $\begin{array}{l}\text { Death after weaning if } \\
\text { not treated with } \mathrm{TH}\end{array}$ & NR & NR & Marians and cols. (63) \\
\hline Hyt/hyt & $\begin{array}{l}\text { Loss of function } \\
\text { mutation in TSHR gene }\end{array}$ & $\begin{array}{l}\text { Low TH; elevated TSH } \\
2000 \text { fold }\end{array}$ & $\begin{array}{l}\text { Linear growth } \\
\text { retardation, delayed } \\
\text { endochondral } \\
\text { ossification, reduced } \\
\text { cortical bone, reduced } \\
\text { mineralization }\end{array}$ & NR & Hypothyroid & $\begin{array}{l}\text { Beamer and cols. (64); Gu } \\
\text { and cols. (65) }\end{array}$ \\
\hline D2 & $\begin{array}{l}\text { Type } 2 \text { deiodinase } \\
\text { deleted }\end{array}$ & $\begin{array}{c}\text { Elevated TSH and T4; } \\
\text { normal T3 }\end{array}$ & $\begin{array}{c}\text { Normal growth and } \\
\text { development }\end{array}$ & NR & NR & $\begin{array}{l}\text { Bassett and cols. (5); } \\
\text { Fraichard and cols. (66) }\end{array}$ \\
\hline $\operatorname{TR} \alpha^{0 / 0}$ & $\begin{array}{l}\text { TR } \alpha \text { deleted; } \\
\text { TR } \beta \text { preserved }\end{array}$ & $\begin{array}{c}\text { Euthyroid; normal GH } \\
\text { and IGF-I }\end{array}$ & $\begin{array}{l}\text { Transient growth } \\
\text { retardation; delayed } \\
\text { endochondral } \\
\text { ossification, reduced } \\
\text { mineralization }\end{array}$ & $\begin{array}{c}\text { Osteosclerosis; } \\
\text { increased trabecular } \\
\text { volume, reduction of } \\
\text { osteoclastic absorption }\end{array}$ & Hypothyroid & $\begin{array}{l}\text { Gauthier and cols. (67); } \\
\text { Bassett and cols. (5) }\end{array}$ \\
\hline $\mathrm{TR} \alpha 1^{\mathrm{PV} /+}$ & $\begin{array}{l}\text { TR } \alpha \text { mutation with } \\
\text { heterozygous } \\
\text { dominant negative } \\
\text { TR } \alpha \text { receptor }\end{array}$ & $\begin{array}{l}\text { Mild thyroid failure, } \\
\text { normal GH, reduced } \\
\text { IGF-I }\end{array}$ & $\begin{array}{l}\text { Serious and persistent } \\
\text { growth retardation; } \\
\text { delayed } \\
\text { intramembranous and } \\
\text { endochondral } \\
\text { ossification, reduced } \\
\text { mineralization }\end{array}$ & NR & Hypothyroid & $\begin{array}{l}\text { Kaneshige and cols. (68); } \\
\text { O'Shea and cols. (69) }\end{array}$ \\
\hline $\operatorname{TR} \beta^{--}$ & $\begin{array}{l}\text { TR } \beta \text { deleted; } \\
\text { TR } \alpha \text { preserved }\end{array}$ & $\begin{array}{l}\text { RTH with elevated TH } \\
\text { and goiter }\end{array}$ & $\begin{array}{c}\text { Persistent short } \\
\text { stature; advanced } \\
\text { ossification, increased } \\
\text { mineralization }\end{array}$ & $\begin{array}{l}\text { Osteoporosis, reduced } \\
\text { mineralization, } \\
\text { increased osteoclastic } \\
\text { resorption }\end{array}$ & Thyrotoxic & $\begin{array}{c}\text { Forrest and cols. (69); } \\
\text { Gauthier and cols. (67); } \\
\text { Bassett and cols. (5) }\end{array}$ \\
\hline $\operatorname{TR} \beta^{\text {PVVPV }}$ & $\begin{array}{c}\text { TR } \beta \text { mutantion with } \\
\text { homozigous dominant } \\
\text { negative TR } \beta \text { receptor }\end{array}$ & $\begin{array}{l}\text { RTH serious and } \\
\text { goiter; reduced GH }\end{array}$ & $\begin{array}{l}\text { Accelerated prenatal } \\
\text { growth; retarded } \\
\text { persistent postnatal } \\
\text { growth; advanced } \\
\text { ossification; increased } \\
\text { mineralization }\end{array}$ & NR & Thyrotoxic & $\begin{array}{l}\text { Kaneshige and cols. (70); } \\
\text { 0'Shea and cols. (12); } \\
\text { Bassett and cols. (5) }\end{array}$ \\
\hline $\operatorname{TR} \alpha^{-/-\operatorname{TR}} \beta^{-/-}$ & $\operatorname{TR} \alpha$ and $\operatorname{TR} \beta$ deleted & RTH and small goiter & $\begin{array}{l}\text { Growth retardation, } \\
\text { delayed ossification, } \\
\text { reduced mineralization }\end{array}$ & $\begin{array}{l}\text { Death near the } \\
\text { weaning }\end{array}$ & NR & $\begin{array}{l}\text { Gauthier and cols. (67); } \\
\text { Bassett and cols. (5) }\end{array}$ \\
\hline
\end{tabular}

TH: thyroid hormone; TSHR: thyroid stimulating hormone receptor; D2: type 2 deiodinase; TR $\alpha$ : thyroid hormone receptor alpha; TRß: thyroid hormone receptor beta; RTH: resistance to thyroid hormone; NR: not reported.

\section{Consequences for development}

Childhood and adolescence are periods of great skeletal changes, when more than $90 \%$ of the bone mass is acquired. During the prepubertal period, bone growth and mineralization are more rapid in the limbs than in the spine (17). Spine growth accelerates during early and intermediate puberty and both axial an appendicu- lar bone undergoes reduced growth at the end of puberty. At seven years of age, girls have already reached $80 \%$ of their adult height, but have acquired only $40 \%$ of their adult bone mass. At about 7 years of age, boys reach $70 \%$ of their final height, but only $35 \%$ of their bone mass. The peak of mineralization occurs about eight months after the peak growth rate; thus, bones 
are relatively less mineralized during the peripubertal period, contributing to the risk of fractures during this phase. Between six and 16 years of age, bone mass increases 2.5 and 3 times in girls and boys, respectively. The peak of bone mass reached at the beginning of adult life is a major determinant of osteoporosis emergence after reproductive age (17). Although genetic factors determine 60 to $80 \%$ of the variability of skeletal bone mass, other factors related to health and life style can significantly influence bone growth and remodeling. Among these factors are various hormones such as estrogens (18), androgens and GH (19), with anabolic effects, glucocorticoids with catabolic actions $(20,21)$ and $\mathrm{TH}$ with a variable effect depending on the phase of development. T3 is known to be a potent regulator of skeletal growth and maturation, with its actions on bone varying according to developmental stage, with predominance of anabolism during development and of catabolism after bone maturation (22).

\section{Hypothyroidism and thyrotoxicosis}

In children, $\mathrm{TH}$ deficiency leads to delayed maturation, short stature and changes in the epiphyseal growth plates, while $\mathrm{TH}$ excess results in advanced bone age, premature fusion of the epiphyses, and consequent limitation of final stature $(23,24)$.

The relative expression of the two TR genes also varies, not only among tissues, but also during the different phases of development. It has been demonstrated that the TR $\alpha \mathrm{l}$ and TR $\beta 1$ isoforms are functionally present at varying proportions in three osteosarcoma cell lines which express fibroblast, preosteoblast and mature osteoblast phenotypes (ROS 25/1, UMR 106 and ROS $17 / 2.8$, respectively), suggesting a possible change in $\mathrm{TH}$ action during bone development (25). Indeed, these cells show different responses to T3 treatment.

Together with GH, IGFs, glucocorticoids, estrogens and androgens, $\mathrm{TH}$ represent important systemic factors that influence bone growth and maturation, especially after the beginning of puberty. Under normal conditions, TH activates both synthesis and degradation of bone matrix, having relevant role for skeletal integrity maintenance (8). One of the mechanisms by which $\mathrm{TH}$ produce these effects is an indirect action increasing GH and IGF secretion (26), as reported in classical studies on thyroidectomized rats treated with $\mathrm{TH}$. After thyroidectomy, the animals show a reduction of pituitary and serum circulatory levels of $\mathrm{GH}$, which is reversed after $\mathrm{TH}$ replacement. Additionally, there is evidence that $\mathrm{TH}$ can act directly on the epiphyseal plate independently of GH (26), as demonstrated in studies with cultures of epiphyseal plate cells submitted to a T3-rich environment. Within this context, there is inhibition of the clonal expansion of immature chondrocytes in parallel to an increased differentiation of hypertrophic chondrocytes, the latter representing the end phase of life of these cells, when they can no longer promote growth.

The final height can be impaired by both lack and excess of TH. Spontaneous nocturnal secretion of GH is low in hypothyroidism and hyperthyroidism $(27,28)$. The rate and the amount of GH released are reduced in adolescents with untreated thyrotoxicosis compared with normal controls. It has been proposed that the reduced GH release during GHRH stimulation in hyperthyroidism may be explained in part by an increase in hypothalamic somatostatin tone with a concomitant decrease in GHRH (28). While in the presence of thyrotoxicosis the impairment of height occurs in a proportionate manner, congenital hypothyroidism is the only cause of secondary disproportionate short stature, mainly affecting the lower segment of the body.

\section{Resistance to thyroid hormones}

In 2012, it was reported the first cases of resistance to TH (RTH) due to mutation in THRA gene (RTH $\alpha$ ). The skeletal phenotype of these individuals was marked by disproportionate short stature. They also had delayed skeletal maturation as well as retarded closure of cranial sutures and tooth eruption. This strong evidence indicates that TR $\alpha$ l plays a fundamental role in bone development $(29,30)$. In contrast, in cases of RTH due to mutation in THRB gene (RTH $\beta)$, proportionate short stature and delayed bone age were detected at proportions ranging from 8 to $18 \%$ and from 29 to $47 \%$, respectively $(31,32)$. The last condition was first reported in 1967 by Refetoff and cols. (33), with the description of more than 3,000 individuals affected distributed among more than 1,000 families, with the identification of more than 170 mutations in the THRB gene (34). In a study of 14 Brazilian patients with RTH $\beta, 8$ adults and 6 children, short stature (below the 3 rd percentile of the growth curve) was observed in 2 adults (14.3\%), and no significant delay or advancement of bone age was detected (35). It is 
not known whether the delay in bone age occurring in some of these individuals with RTH $\beta$ is primarily due to TR $\beta$ dysfunction per se or to the negative dominant effect that mutants may exert on normal TR $\alpha$ l, preventing their full physiological role.

\section{Consequences for bone mass}

The bone remodeling process is an ingenious mechanism that simultaneously contributes to calcium homeostasis and bone resistance. Under ideal conditions, the final product of bone remodeling is the maintenance of bone integrity (8). Conversely, imbalance in bone formation and resorption leads to bone loss and deterioration of bone microarchitecture, with consequent emergence of bone fragility and an increased risk of fractures $(9)$.

\section{Hypothyroidism and thyrotoxicosis}

The intracellular TH metabolism performed by deiodinases D2 (activator) and D3 (inactivator) in the osteoblasts is a sophisticated mechanism for the maintenance of intracellular T3 concentrations in a manner partially independent of its serum concentrations. Thus, D2 activity is maximum in hypothyroidism and minimum in thyrotoxicosis, in order to maintain constant intracellular T3 concentrations. These adaptations may play an important role by preserving bone mineralization and strength during the phase of installation of thyroid disorders. However, when hypothyroidism and thyrotoxicosis become established, this local feedback mechanism is unable to maintain T3 in bone microenvironment, with the occurrence of increased (hypothy- roidism) or reduced (hyperthyroidism) mineralization, and repercussions on bone mass and strength. Thus, an increased risk of fractures occurs in hypothyroidism due to stiffness and instability, or due to fragility in thyrotoxicosis. Expectedly, the risk of fracture according to thyroid status, follows a "U"-shaped curve, with the risk being lower in euthyroidism and increasing with both the lack and the excess of $\mathrm{TH}(7,8)$. The main changes and consequences of $\mathrm{TH}$ excess or deficiency are summarized in table 2 .

Hypothyroidism leads to a low bone turnover, with a reduction of osteoclast bone reabsorption and of osteoblast formation, slowing the remodeling process and increasing the time taken in the remodeling cycle, mainly due to the prolongation of the mineralization phase. A slight increase in bone mass may even occur, which unfortunately does not result in a reduced risk of fracture. On the contrary, the risk of fracture arises before bone mass reaches levels compatible with osteoporosis. Although the mechanisms are not fully understood, impairment of bone quality is believed to occur in association with the reduction of mechanical stimuli due to lower physical activity and with an increased risk of falls (36-38).

In contrast, in thyrotoxicosis there is an increase in bone turnover, with a reduction of the cycle mainly impairing the phase of bone formation, with decoupling of the remodeling process in favor of reabsorption. As a consequence bone loss occurs; indeed hyperthyroidism is a major cause of secondary osteoporotic fractures. The catabolic effects of $\mathrm{TH}$ in bone were described more than one century ago, and the clinical repercussion in BMD and risk of fractures have been fully characterized more recently in untreated hyperthyroid

Table 2. Main effects of thyroid hormone deficiency or excess on bone turnover in young adult skeleton

\begin{tabular}{lcc}
\hline & Hypothyroidism & Thyrotoxicosis \\
\hline On bone remodeling cycle & Maximum & Minimum \\
D2 activity & Reduced & Increased \\
Osteoblastic and osteoclastic activity & Prolonged, mainly at the expense of increasing the & Reduced, mainly to the detriment of the formation \\
Duration of bone remodeling cycle & resorption phase & Increased \\
On young skeleton & & Increased \\
Growth velocity & Reduced & Increased \\
Bone mineralization & Reduced & Reduced and proportioned \\
Intramembranous ossification/Bone age & Reduced & Reduced \\
Final stature & Reduced and disproportionate \\
On adult skeleton & Increased & Increased, by fragility \\
Bone mass & Increased, by stiffness & \\
Risk of fractures & &
\end{tabular}


subjects. Histomorphometry studies in thyrotoxicosis have demonstrated increased osteoblast and osteoclast activity (11). The evaluation of bone histomorphometry on humans and animals have shown that, in the presence of excess $\mathrm{TH}$, osteoblast and osteoclast activity is increased, with a predominance of the latter. As a result, bone metabolism is accelerated, favoring resorption and a negative calcium balance and as a result bone loss $(37,38)$. The ensuing structural changes involve reduction of the thickness and number of trabeculae, implying in a reduction of trabecular bone volume. There is also increased porosity and reduced thickness of cortical bone. Bone fragility has been reported as an early adverse effect that may arise even in subclinical hyperthyroidism (5).

An important clinical aspect that emphasizes the negative impact of hyperthyroidism on the skeleton is the bone recomposition that follows the reestablishment of normal TH production. However, there is still controversy about whether this recovery is total or partial $(39,40)$. A 2003 meta-analysis study has suggested that treatment of hyperthyroidism alone restores bone mass to normal levels after one to four years, even when no other measure is taken to increase bone mass (41).

Although all skeletal sites are responsive to $\mathrm{TH}$, they exhibit different response to $\mathrm{TH}$ stimuli. The long-term administration of high LT4 doses to adult male rats for a period of 3 to 20 weeks resulted in reduced bone mineral density (BMD) in the femur but not in vertebrae. There was also a significant increase in the expression of osteocalcin, osteopontin, alkaline phosphatase and tartrate-resistant acid phosphatase in the femur, but not in the spine specimen. $(42,43)$. In clinical investigation, hyperthyroidism seems to affect cortical bone to a greater extent than trabecular bone, demonstrated by predominant bone loss in the forearm (44). The variability in response pattern is probably related to the differential expression not only of TRs, but also of other factors that modulate bone remodeling (45).

It is also possible that $\mathrm{TH}$ may interfere with the bioavailability and action of estradiol and/or androgens, since both hypo- and hyperthyroidism can cause significant changes in the bioavailability of these steroids (46). These changes range from elevation of sex hormone binding globulin (SHBG), estradiol and testosterone, in the case of thyrotoxicosis, to reduction of these parameters in hypothyroidism. Both $\operatorname{TR} \alpha$ and $\operatorname{TR} \beta$ are expressed in the testicles and TR $\alpha \mathrm{l}$ is the isoform most likely associated with testicular development and function (47). The ovaries also express TRs, inclusive mRNA of TR $\alpha 1, T R \beta 1, T R \beta 2$ and c-erb-TR $\Delta \alpha 2$ having been detected in human oocytes (48). These data indicate the existence of a strict interaction between the gonadal and thyroid axis. Certainly, this is one of the multiple mechanisms involved with the emergence of bone disease in patients showing thyroid disorders.

\section{Resistance to thyroid hormone}

Animal models of congenital hypothyroidism, thyrotoxicosis and RTH due to THRA and THRB genes deletions or mutations have greatly contributed to the understanding of osteomineral metabolism in different thryoid conditions. The models of TH deficiency, usually due to PAX8 or TSHR mutation, as well as TR $\alpha$ mutants, present a skeletal phenotype of hypothyroidism, with the animals showing reduced mineralization, growth retardation and delayed ossification during development, but with increased mineralization after maturation $(5,12)$. In human beings, an especially curious clinical model of primary hypothyroidism is congenital hypothyroidism due to thyroid dysgenesis. In addition to low serum $\mathrm{TH}$ levels, affected individuals show reduced circulating levels of calcitonin. Previous studies have shown that adult patients with thyroid dysgenesis who started $\mathrm{TH}$ replacement during different phases of childhood have a normal bone mass despite the concomitant chronic calcitonin deficiency.

In contrast, experimental models of TH excess usually involve treatment with T3 and TR $\beta$ mutants. The thyrotoxic skeletal phenotype varies from increased mineralization and advanced ossification during development to reduced mineralization after maturation $(5,12)$. Other experimental models, such as mutants for D2 and dual oxidase (Duox2), the enzyme generating hydrogen peroxide which permits the action of thyroperoxidase, are more complex. In the former, they show normal skeletal growth and development although with stiff bones due to increased bone mineralization. In the last, the bone phenotype still is to be characterized (42).

Diverse bone phenotypes have been described in patients harboring RTH. No involvement of bone mass was observed in individuals with RTH $\alpha$ compared to controls, whereas adults showing RTH $\beta$ have decreased bone mass (35). These data suggest that RTH $\beta$ in human is associated with a thyrotoxic bone phenotype and similar results have been found in animal model. 


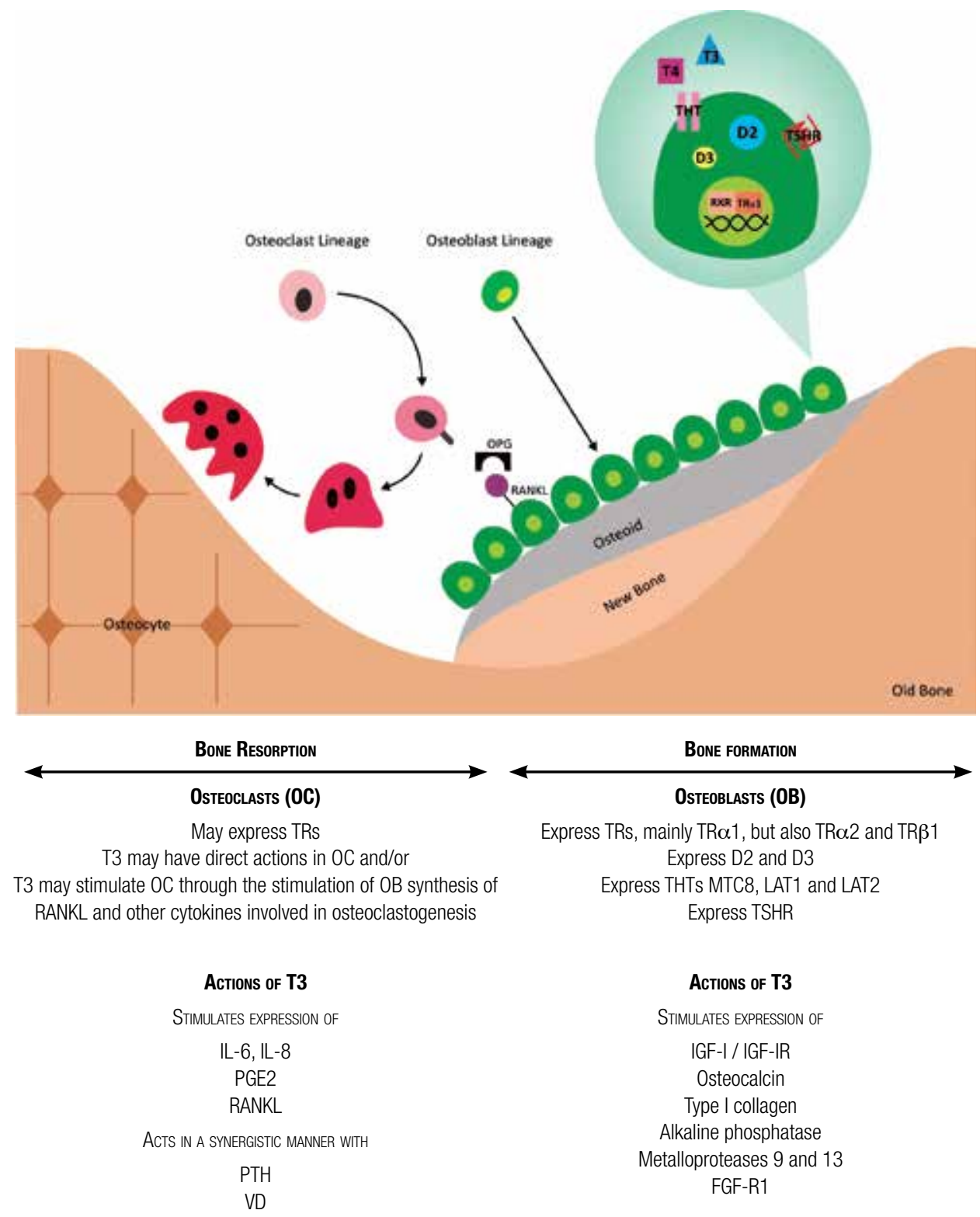

Figure 1. Interface between TH and bone metabolism. Bone remodeling on the surface of trabecular bone is illustrated here. T3 stimulates osteoblast differentiation and activity by complex direct actions on TRs and indirect mechanisms, involving diverses growth factors and cytokines. T3 also stimulates osteoclast differentiation and activity, but it still remains unclear whether the effects of $\mathrm{T} 3$ on the promotion of bone resorption result from direct actions in osteoclasts or indirectly through effects on osteoblasts. TR, thyroid hormone receptor; IL-6, interleukin 6; IL-8, interleukin 8; PGE2, prostaglandin E2; RANKL, ligand of receptor activator of nuclear factor- $\kappa \beta$; PTH, parathyroid hormone; VD, vitamin D; D2, type 2 deiodinase; D3, type 3 deiodinase; THT, thyroid hormone transporters; MCT8, monocarboxilate transporter 8; LAT: L-type amino acid transporter; TSHR, TSH receptor; IGF-I, insulin-like growth factor I; IGF-IR, IGF-I receptor.

\section{Consequences for osteomineral metabolism}

Over the last two decades there has been a significant advance in the understanding of bone physiology. It has been unequivocally determined that the skeleton has a marked metabolic activity, utilizing substrates in order to provide the energy used in the bone remodeling process. In addition, bone is involved in the endocrine modulation not only of mineral metabolism, but also of energy metabolism. The fibroblast growth factor 23 (FGF-23), originally produced by osteocytes, shares with PTH an important role on the modulation of circulatory levels of phosphate. In parallel, FGF-23 inhibits the production of both PTH and calcitriol $\left[1,25(\mathrm{OH})_{2} \mathrm{D}\right](49)$. The anatomical structure enables trabecular bone to have greater metabolic activity than its cortical counterpart (49). Bone remodeling is regulated by a variety of systemic hormones and local factors that act on osteoblast and/or osteoclast cell lines, 
exerting effects on the proliferation of undifferentiated cells and on cell recruitment, differentiation and/or activation (49). Among the main systemic hormones that participate in the modulation of bone metabolism are the so-called calciotrophic hormones, which include PTH, 1,25( OH $)_{2} \mathrm{D}$ and calcitonin, the last one of less importance. In addition, $\mathrm{TH}$, together with insulin, growth hormone, glucocorticoids and sex steroids, have a significant influence on the development and maintenance of bone mass (8).

\section{Hypothyroidism and thyrotoxicosis}

Hyperthyroidism causes important changes in calcium and phosphorus metabolism which may lead to an increase of as much as three times of the urinary and fecal excretion of calcium. The action of $\mathrm{TH}$ on renal phosphorus reabsorption starts early, during development. For instance, it was observed that $\mathrm{TH}$ promote the maturation of tubular phosphate transporters in rats. Although TH increase the total urinary excretion of phosphorus, they also increase the renal reabsorption of phosphorus by activating phosphorus channels dependent on the sodium gradient (50-52).

The hypercalcemia of thyrotoxicosis may result from an abnormal calcium efflux from the skeleton, kidneys and gastrointestinal tract to the extracellular fluid. The trend to hypercalcemia in thyrotoxicosis has been documented and its incidence varies from 8 to $22 \%$. It is usually mild, but occasionally it is severe enough to be symptomatic and rarely is associated with signs and symptoms of acute hypercalcemia. The mean serum calcium concentrations of hyperthyroid patients are higher than those of control subjects (53-55). Previous studies have shown that hypercalcemia in thyrotoxicosis is mainly due to increased mineral bone mobilization. This in turn is caused by a direct stimulation of bone cells by the high TH concentrations, with a consequent increase in bone reabsorption. It has been demonstrated that T3 increased the mRNA expression of the RANKL in preosteoblastic cells. The RANKL is a key molecule for osteoclastogenesis and osteoclast activation. It is synthesized and secreted by the osteoblasts and binds to its receptor, RANK, expressed on osteoclast precursors and mature osteoclasts, thus activating osteoclastogenesis and osteoclast activity $(7,8)$. Indeed, in patients with thyrotoxicosis, bone histomorphometry is consistent with increased osteoclast reabsorption in cortical bone, leading to increased cortical porosity, while in cancelous bone these changes are less evident. The biochemical markers of bone formation and reabsorption, such as osteocalcin (OC), alkaline phosphatase $(\mathrm{AP})$, bone-specific $\mathrm{AP}$, urinary pyridinoline and deoxypyridinoline, are increased in patients with hyperthyroidism, indicating enhanced bone remodeling activity.

The increased mineral bone mobilization and consequent hypercalcemia, may lead to the suppression of PTH release in patients with thyrotoxicosis. It has also been reported that hyperphosphatemia, hypercalciuria and hyperphosphaturia frequently occur in these patients $(53,54)$. The calcium balance in patients with untreated hyperthyroidism is negative and the losses do not seem to be due to VD deficiency, since they are not reduced by VD treatment (55). Some authors have also proposed that hypercalcemia in thyrotoxicosis may be due to increased adrenergic tonus. In support to this hypothesis there are studies showing that thyrotoxic patients with hypercalcemia may become normocalcemic after therapy with propranolol alone. Moreover the serum levels of bone turnover markers (e.g., alkaline phosphate and osteocalcin) are elevated in hyperthyroidism, and remain high for months during its treatment, despite normalization of serum $\mathrm{TH}(54)$.

Regarding phosphorus metabolism in hyperthyroidism, the findings are more conflicting. Some authors have reported that thyrotoxicosis courses with hyperphosphatemia, while others detected normal phosphorus concentrations, and hypophosphatemia $(50,53,54)$. Hyperphosphatemia in hyperthyroidism appears to be caused by: increased bone reabsorption and tubular phosphate reabsorption; a direct action of $\mathrm{TH}$ on the renal N/Pi transporters and by PTH suppression induced by hypercalcemia. In the kidneys, studies using immunocytochemistry and specific antibodies against TR $\alpha$ and TR $\beta$ have demonstrated the presence of both isoforms in all segments of the proximal tubules. Hyperphosphatemia due to excess TH also seems to trigger compensatory mechanisms for the increase in phosphaturia. Recent studies reported that patients with Graves disease exhibit high serum levels of FGF-23, however this occurrence is exclusive of patients with hyperphosphatemia (56). In other words, the increase in FGF-23 secretion appears to be a consequence of high phosphorus concentrations and not an event secondary to the direct action of $\mathrm{TH}$.

Studies investigating the influence of TH on PTH concentration have produced contradictory results. 
Some studies have demonstrated that PTH concentrations are unchanged in the presence of hyperthyroidism (57-59), others have shown an increase in PTH, while most investigations have indicate a phenomenon of counterregulation between PTH and TH $(9,20,41)$. It has been demonstrated that treatment with $\mathrm{T} 3$ increases the number of PTH receptors in osteoblastic osteosarcoma cells in a time- and dose-dependent manner. Also it has been shown that treatment with PTH increases the number of TRs, suggesting a synergism between these two hormones in the regulation of bone metabolism (9).

There is evidence that T3 and VD act synergistically on osteoclastogenesis. It has been demonstrated that the $\alpha$ and $\beta$ TR isoforms and vitamin D receptors (VDR), in addition to estrogen and androgen receptors, are coexpressed in the bone marrow of mice, suggesting that this is a prerequisite for this synergism for osteoclastogenesis (10). In another study on co-cultures of pre-osteoblasts with bone marrow cells, T3 increased the osteoclast formation induced by VD. T4 had the same effects, suggesting its local metabolization to T3, which later led to the identification of the expression of D2 mRNA in pre-osteoblastic cells. It has also been demonstrated that VD increases D2 expression in these cells in a time- and dose-dependent manner, indicating the presence of an additional synergistic mechanism between VD and T3 in osteoclastogenesis (10).

\section{Resistance to thyroid hormone}

No studies have evaluated osteomineral metabolism in RTH $\alpha$. In RTH $\beta$ low serum phosphorus concentrations and renal threshold for phosphate loss have been observed $(35,60)$. Additionally it was observed higher serum levels of FGF-23 and calcium concentrations in these patients compared to control subjects (35). These data represent a challenge for new studies to unveil the control of calcium and phosphorus homeostasis and fracture risk in these patients.

\section{CONCLUSIONS}

The molecular mechanisms of the actions of TH on the skeleton are complex and only partially understood, occurring in a direct and indirect manner. The phenotypes developed by a wide variety of mutant mice suggest that a complex interaction of different TR isoforms with their target genes mediates the effects of $\mathrm{TH}$ on bone tissue, indicating that the skeleton is an important target of T3. TH play a fundamental role in endochondral ossification, in skeletal development and growth, and in the maintenance of bone mass, predominantly through the action of TR $\alpha$ l.

Acknowledgements: writing this review and clinical investigation was enabled by support from National Council for Scientific and Technological Development (CNPq), (FJAP 306027/2011-9) and FAEPA.

Disclosure: no potential conflict of interest relevant to this article was reported.

\section{REFERENCES}

1. Williams GR, Harvey CB. Mechanism of thyroid hormone action. Thyroid. 2002;12(6):441-6.

2. Kinne A, Schülein R, Krause G. Primary and secondary thyroid hormone transporters. Thyroid Res. 2011;3(4)Suppl 1:S7.

3. Lazar MA. Thyroid hormone receptors: multiple forms, multiple possibilities. Endocr Rev. 1993;14:184-93.

4. Capelo LP, Beber EH, Fonseca TL, Gouveia CH. The monocarboxylate transporter 8 and L-type amino acid transporters 1 and 2 are expressed in mouse skeletons and in osteoblastic MC3T3-E1 cells. Thyroid. 2009;19:171-80.

5. Bassett JH, Williams GR. The skeletal phenotypes of TRalpha and TRbeta mutant mice. J Mol Endocrinol. 2009;42:269-82.

6. Abe E, Marians RC, Yu W, Hu XB, Ando T, LiY, et al. TSH is a negative regulator of skeletal remodeling. Cell. 2003;115(2):151-62.

7. Nicholls JJ, Brassill NJ, Williams GR, Bassett JHD. The skeletal consequences of thyrotoxicosis. J Endocrinol. 2012;213:209-21.

8. Gouveia $\mathrm{CH}$. O efeito molecular e estrutural do hormônio tireoidiano no esqueleto. Arq Bras Endocrinol Metab. 2004;48/1:183-95.

9. Gu WX, Stern PH, Madison LD, Du GG. Mutual up-regulation of thyroid hormone and parathyroid hormone receptors in rat osteoblastic osteosarcoma 17/2.8 cells. Endocrinology. 2001;142:157-64.

10. Gruber R, Czerwenka K, Wolf F, Ho GM, Willheim M, Peterlik M. Expression of vitamin $\mathrm{D}$ receptor, of estrogen and thyroid hormone receptor alpha- and beta-isoforms, and the androgen receptor in cultures of native mouse bone marrow and of stromal/osteoblastic cells. Bone. 1999;24:465-73.

11. Freitas FR, Moriscot AS, Jorgetti V, Soares AG, Passarelli M, Scanlan TS, et al. Spared bone mass in rats treated with thyroid hormone receptor TR $\beta$-selective compound GC-1. Am J Physiol Endocrinol. 2003;285:E1135-41.

12. O'Shea PJ, Basset JHD, Sriskantharajah S, Ying $H$, Cheng $S$, Williams GR. Contrasting skeletal phenotypes in mice with an identical mutation targeted to thyroid hormone receptor alpha1 ou beta. Mol Endocrinol. 2005;19(12):3045-59.

13. Varga F, Rumpler M, Klaushofer K. Thyroid hormone increase insulin-like growth factor mNRA levels in the clonal osteoblastic cell line MC3T3-E1. FEBS Lett. 1994;345:67-70.

14. Gouveia $\mathrm{CH}$, Christoffolete MA, Zaitune CR, Dora JM, Harney JW, Maia AL, et al. Type 2 iodothyronine selenodeiodinase is expressed throughout the mouse skeleton and in the MC3T3-E1 mouse osteoblastic cell line during differentiation. Endocrinology. 2005;146:195-200.

15. Gallford TM, Murphy E, Williams AJ, Basset JHD, Williams GR. Effects of thyroid status on bone metabolism: a primary role for 
thyroid stimulating hormone or thyroid hormone. Minerva Endocrinol. 2005;30:237-46.

16. Ma R, Morshed S, Latif R, Zaidi M, Davies TF. The influence of thyroid-stimulating hormone and thyroid-stimulating hormone receptor antibodies on osteoclastogenesis. Thyroid. 2011;21(8):897-906.

17. Bachrach LK. Skeletal development in childhood and adolescence. In: Rosen C (ed.). Primer on the metabolic bone diseases and disorders of mineral metabolism. Seventh Edition. An official publication of The American Society for Bone and Mineral Research. 2008;14:74-80.

18. Alessandri SB, Pereira Fde A, Villela RA, Antonini SR, Elias PC, Martinelli CE Jr, et al. Bone mineral density and body composition in girls with idiopathic central precocious puberty before and after treatment with a gonadotropin-releasing hormone agonist. Clinics (Sao Paulo). 2012;67(6):591-6.

19. Gois MB Jr, Salvatori R, Aguiar-Oliveira MH, Pereira FA, Oliveira $\mathrm{CR}$, Oliveira-Neto LA, et al. The consequences of growth hormone-releasing hormone receptor haploinsufficiency for bone quality and insulin resistance. Clin Endocrinol (Oxf). 2012;77(3):379-84.

20. Lanna CM, Paula FJ, Montenegro RM Jr, Moreira AC, Foss MC. Parathyroid hormone secretion in chronic human endogenous hypercortisolism. Braz J Med Biol Res. 2002;35(2):229-36.

21. Lanna CM, Paula FJ, Montenegro RM Jr. Fisiopatologia da osteoporose induzida por glicocorticóide. Arq Bras Endocrinol Metab. 2003;47(1):9-18.

22. Waung JA, Bassett JHD, Williams GR. Thyroid hormone metabolism in skeletal development and adult bone maintenance. Trends Endocrinol Metab. 2011;23(4):155-62.

23. Boersma B, Otten BJ, Stoelinga GB, Wit JM. Catch-up growth after prolonged hypothyroidism. Eur J Pediatr. 1996;155:362-7.

24. Segni M, Gorman CA. The aftermath of childhood hyperthyroidism. J Pediatr Endocrinol Metab. 2001;14:1277-82.

25. Williams GR, Bland R, Sheppard MC. Characterization if thyroid hormone (T3) receptors in three osteosarcoma cell lines of distinct osteoblast phenotype: interactions among T3, vitamin D3, and retinoid signaling. Endocrinology. 1994;136:4304-14.

26. Robson H, SieblerT, Stevens DA, Shalet SM, Williams GR. Thyroid hormone acts directly on growth plate chondrocytes to promote hypertrophic differentiation and inhibit clonal expansion and cell proliferation. Endocrinology. 2000;141:3887-97.

27. Katz HP, Youlton R, Kaplan SL, Grumbach MM. Growth and growth hormone release in children with primary hypothyroidism and thyrotoxicosis. J Clin Endocrinol Metab. 1969;29:346-8.

28. Chernausek SD, Turner R. Attenuation of spontaneous, nocturnal growth hormone secretion in children with hypothyroidism and its correlation with plasma insulin-like growth factor-l concentration. J Pediatr. 1989;114:968-72.

29. Bochukova E, Schoenmakers N, Agostini M, Schoenmakers E, Rajanayagam O, Keogh JM, et al. A mutation in the thyroid hormone receptor alpha gene. N Engl J Med. 2012;366(3):243-9.

30. Moran C, Schoenmakers N, Agostini M, Schoenmakers E, Offiah $A$, Kydd A, et al. An adult female with resistance to thyroid hormone mediated by defective thyroid hormone receptor alpha. $J$ Clin Endocrinol Metab. 2013;98(11):4254-61.

31. Brucker-Davis F, Skarulis MC, Grace MB, Benichou J, Hauser $P$, Wiggs $E$, et al. Genetic and clinical features of 42 kindreds with resistance to thyroid hormone. The National Institutes of Health Prospective Study. Ann Intern Med. 1995;123(8):572-83.

32. Weiss RE, Refetoff S. Effect of thyroid hormone on growth. Lessons from the syndrome of resistance to thyroid hormone. Endocrinol Metab Clin North Am. 1996;25(3):719-30.

33. Refetoff $S$, DeWind LT, DeGroot LJ. Familial syndrome combining deaf-mutism, stippled epiphyses, goiter, and abnormally high
PBI: possible target organ refractoriness to thyroid hormone. J Clin Endocrinol Metab. 1967;27:279-94.

34. Dumitrescu AM, Refetoff S. The syndromes of reduced sensitivity to thyroid hormone. Biochim Biophys Acta. 2013;1830(7):39874003.

35. Cardoso LF, de Paula FJA, Maciel LMZ. Evaluation of bone and mineral metabolism in patients with the syndrome of resistance to thyroid hormone. XV Latin American Thryoid Congress LATS. Florianópolis, Brazil, March 20-23/2013:130.

36. Mundy GRaC D, Oyajobi BO. Bone remodeling. In: Favus MJ, ed. Primer on the metabolic bone diseases and disorders of mineral metabolism. 5th ed. Washington, DC: American Society for Bone and Mineral Research. 2003. p. 28-31.

37. Bassett JH, Boyde A, Howell PG, Bassett RH, Galliford TM, Archanco $\mathrm{M}$, et al. Optimal bone strength and mineralization requires the type 2 iodothyronine deiodinase in osteoblasts. Proc Natl Acad Sci USA. 2010;107(16):7604-9.

38. Vestergaard P, Bassett L. Fractures in patients with hyperthyroidism and hypothyroidism: a nationwide follow-up study in 16,249 patients. Thyroid. 2002;12:411-19.

39. Gorka J, Taylor-Gjevre RM, Arnason T. Metabolic and clinical consequences of hyperthyroidism on bone density. Int J Endocrinol. 2013;2013:638727. doi: 10.1155/2013/638727. Epub 2013 Jul 22.

40. Allain TJ, Thomas MR, McGregor AM, Salisbury JR. A histomorphometric study of bone changes in thyroid dysfunction in rats. Bone. 1995;16:505-9.

41. Mosekilde L, Melsen F, Christensen MS. Interrelationships between bone morphometry, thyroid function tests and serum parathyroid hormone in hyperthyroidism. Calcif Tissue Res. 1977;22:229-35.

42. Vestergaard P, Mosekilde L. Hyperthyroidism, bone mineral and fracture risk - a meta-analysis. Thyroid. 2003;13:585-93.

43. Johnson KR, Marden CC, Ward-Bailey P, Gagnon LH, Bronson RT, Donahue LR. Congenital hypothyroidism, dwarfism, and hearing impairment caused by a missense mutation in the mouse dual oxidase 2 gene, Duox2. Mol Endocrinol. 2007;21:1593-602.

44. Gouveia $\mathrm{CH}$, Jorgetti V, Bianco AC. Effects of thyroid hormone administration and estrogen deficiency on bone mass of female rats. J Bone Miner Res. 1997;12:2098-107.

45. Suwanwalaikorn S, Ongphiphadhanakul B, Braverman LE, Baran DT. Differential responses of femoral and vertebral bones to long-term excessive L-thyroxine administration in adult rats. Eur J Endocrinol. 1996;134:655-9.

46. Krassas GE, Poppe K, Glinoer D. Thyroid function and human reproductive health. Endocrine Reviews. 2010;31(5):702-55.

47. Buzzard JJ, Morrison JR, O'Bryan MK, Song Q, Wreford NG. Developmental expression of thyroid hormone receptors in the rat testis. Biol Reprod. 2000;62:664-9.

48. Zhang SS, Carrillo AJ, Darling DS. Expression of multiple thyroid hormone receptor mRNAs in human oocytes, cumulus cells, and granulosa cells. Mol Hum Reprod. 1997;3(7):555-62.

49. de Lima, Nobrega LHC, de Mendonça RP. Introdução ao metabolismo ósseo e mineral. In: Bandeira F, Graf H, Griz L, Faria M, Lazaretti-Castro M (eds.) Endocrinologia e Diabetes, 2.ed., Rio de Janeiro: Medbook - Editora Científica Ltda. 2009;363-8.

50. Persons V, Anderson J. The maximum renal tubular reabsortive rate for inorganic phosphate in thyrotoxicosis. Cli Sci. 1964;27:313-8.

51. Espinosa RE, Keller MJ, Yusufi ANK, Dousa TP. Effect of thyroxine administration on phosphate transport across renal cortical brush border membrane. Am J Physiol. 1984;246(15):F133-9.

52. Euzet $S$, Lelievre-Pegorier M, Merlet-Benichou C. Maturation of rat renal phosphate transport: effects of triiodothyronine. J Physiol. 1995;488(Pt 2):449-57. 
53. Mosekilde L, Eriksen EF, Charles P. Effects of thyroid hormones on bone and mineral metabolism. Endocrinol Metab Clin North Am. 1990;19(1):35-63.

54. Pantazi H, Papapetrou PD. Changes in parameters of bone and mineral metabolism during therapy for hyperthyroidism. J Clin Endocrinol Metab. 2000;85(3):1099-106.

55. Veríssimo JMT, de Oliveira HL, Mazzoncini M, Lomonaco DA. Estudo do metabolismo do cálcio na tireotoxicose humana. Rev Assoc Med Brasil. 1965;11:11-23.

56. Yamashita H, Yamazaki Y, Hasegawa H, Yamashita T, Fukumoto S, Shigematsu $\mathrm{T}$, et al. Fibroblast growth factor-23 in patients with Graves' disease before and after antithyroid therapy: its important role in serum phosphate regulation. J Clin Endocrinol Metab. 2005;90(7):4211-5.

57. Langdahl BL, Loft AGR, Eriksen EF, Mokesilde L, Charles P. Bone mass, bone turnover and body composition in former hypothyroid patients receiving replacement therapy. Eur J Endocrinol. 1996;134:702-9.

58. Kumeda $Y$, Inaba M, Tahara $H$, Kurioka $Y$, Ishikawa T, Morii $H$, et al. Persistent increase in bone turnover in Graves' patients with subclinical hyperthyroidism. J Clin Endocrinol Metab. 2000;85:4157-61.

59. Marcocci G, Golia F, Vignali E, Pinchera A. A skeletal integrity in men chronically treated with suppressive doses of thyroxine. J Bone Miner Res. 1997;12:72-7.

60. Dare GLR, Magalhães PKR, Castro M, Maciel LMZ. Peripheral parameters of thyroid hormone action in resistance to thyroid hormone syndrome: a focus on mineral metabolism. Thyroid. 2009;19(7):785-7.

61. Mansouri A, Chowdhury K, Gruss P. Follicular cells of the thyroid gland require Pax8 gene function. Nat Genet. 1998;19:87-90.

62. Friedrichsen S, Christ S, Heuer H, Schafer MK, Mansouri A, Bauer $K$, et al. Regulation of iodothyronine deiodinases in the Pax8-
/- mouse model of congenital hypothyroidism. Endocrinology. 2003;144:777-84.

63. Marians RC, Ng L, Blair HC, Unger P, Graves PN, Davies TF. Defining thyrotropin-dependent and-independent steps of thyroid hormone synthesis by using thyrotropin receptor-null mice. Proc Natl Acad Sci USA. 2002;99:15776-81.

64. Beamer WG, Cresswell LA. Defective thyroid ontogenesis in fetal hypothyroid (hyt/hyt) mice. Anat Rec. 1982;202:387-93.

65. Gu WX, Du GG, Kopp P, Rentoumis A, Albanese C, Kohn LD, et al. The thyrotropin (TSH) receptor transmembran domain mutation (Pro556-Leu) in the hypothyroid hyt/hyt mouse models in plasma membrane targeting but defectiveTSH biding. Endocrinology. 1995;136:3146-53.

66. Fraichard A, Chassande O, Plateroti M, Roux JP, Trouillas J, Dehay $C$, et al.TheT3R alpha gene encoding a thyroid hormone receptor is essential for post-natal development and thyroid hormone production. EMBO J. 1997;16:4412-20.

67. Gauthier K, Chassande O, Plateroti M, Roux JP, Legrand C, Rousset $B$, et al. Different functions for the thyroid hormones receptors TR $\alpha$ and TR $\beta$ in the control of thyroid hormone production and post-natal development. Embo J. 1999;18:623-31.

68. Kaneshige $M$, Suzuki $H$, Kaneshige $K$, Cheng J, Wimbrow $H$, Barlow $\mathrm{C}$, et al. A targeted dominant negative mutation of the thyroid hormone alpha 1 receptor causes increased mortality, infertility, and dwarfism in mice. Proc Natl Acad Sci U S A. 2001;98(26):15095-100.

69. Forrest D, Sjoberg M, Vennstrom B. Contrasting developmental and tissue-specific expression of alpha and beta thyroid hormone receptor genes. EMBO J. 1990;9:1519-28.

70. Kaneshige M, Kaneshige K, Zhu X, Dace A, Garrett L, Carter TA, et al. Mice with a targeted mutation in the thyroid hormone beta-receptor gene exhibit impaired growth and resistance to thyroid hormone. Proc Natl Acad Sci USA. 2000;97:13209-14. 